\title{
CALCIUM: A PROGRAM IN BASIC FOR CALCULATING THE COMPOSITION OF SOLUTIONS WITH SPECIFIED FREE CONCENTRATIONS OF CALCIUM, MAGNESIUM AND OTHER DIVALENT CATIONS
}

\author{
Dean Chang, Paul S. Hsieh and David C. Dawson* \\ Department of Physiology and Cellular and Molecular Biology Program 6811 Medical Science II, \\ Box 0622, University of Michigan Medical School, Ann Arbor, MI 48109-0622, U.S.A. \\ (Received 4 September 1987; in revised form 22 January 1988; received for publication 12 February
} 1988)

\begin{abstract}
A BASIC program is presented which facilitates the formulation of biologically relevant chemical solutions containing specified free concentrations of as many as three divalent metal cations $\left(\mathrm{Ca}^{2+}, \mathrm{Mg}^{2+}\right.$ and the choice of a third divalent cation) at any $\mathrm{pH}$ in the presence of as many as three ligands (EGTA, ATP and GTP). The program uses the law of mass action and the absolute stability (association) constants found in the literature to calculate the total concentration of divalent metal cation needed to achieve a desired free concentration. The user enters the $\mathrm{pH}$, the concentrations of the ligands used and the desired free concentrations of the divalent cations. This program was developed for use in a wide range of biological applications, particularly the rapid design of solutions which mimic certain aspects of intracellular fluid.

BASIC program Free divalent metal cation concentration Calcium

Magnesium EGTA ATP GTP Multi-metal/multi-ligand equilibrium
\end{abstract}

\section{INTRODUCTION}

Calcium plays a central role in the regulation of such diverse cellular processes as muscle contraction, exocytosis, cell division, membrane ion permeability, intermediary metabolism, and signal transduction [1,2]. In experiments designed to examine the effect of calcium on cellular processes, it is advantageous to control free calcium levels in a precise and reproducible manner by means of a calcium-EGTA $\dagger$ buffer system. Furthermore, in the study of signal transduction pathways and intracellular second messengers one is confronted with the need to reconstitute presumed intracellular conditions where calcium, magnesium, ATP and GTP are essential constituents. Magnesium, for example, is a cofactor for many enzymes involved in substrate phosphorylation; ATP is required by kinase enzymes for activity, as well as for other cellular reactions and GTP is utilized during receptor-mediated signal transduction by GTP-binding proteins [3]. In some instances it is advantageous to include a third divalent metal cation. Barium, for example, is used to block $\mathrm{K}^{+}$channels. Iron is important in the function of hemoglobin and the electron transport carriers and some metalloenzymes require $\mathrm{Zn}^{2+}, \mathrm{Mn}^{2+}$ or $\mathrm{Cu}^{2+}$. Heavy metals such as $\mathrm{Hg}^{2+}, \mathrm{Pb}^{2+}$ and $\mathrm{Cd}^{2+}$ are environmental toxins.

The design of a solution with specified $\mathrm{pH}$ and free concentrations of 3 divalent metal cations in the presence of 3 ligands (EGTA, ATP and GTP) involves solving a system of equations describing the multi-metal/multi-ligand equilibria. The calculations required to solve the simultaneous equilibria are laborious. Computer [4] and calculator [5] programs developed for multiple metal and ligand equilibria have been published, but both programs

* Author to whom correspondence and reprint requests should be addressed.

† Abbreviations used: EGTA, ethylene glycol bis(beta-aminoethyl ether)- $N, N, N^{\prime}, N^{\prime}$-tetraacetic acid; BAPTA, 1,2,-bis(ortho-aminophenoxy)-ethane- $N, N, N^{\prime}, N^{\prime}$-tetraacetic acid; ATP, adenosine triphosphate; GTP, guanosine triphosphate; HEPES, $N$-2-hydroxyethylpiperazine- $N$ '-ethanesulfonic acid; MOPS, 3-( $N$-morpholino)propanesullonic acid. 
have limitations. The computer program presented in [4] is too general for biological applications and is unable to accommodate hydroxo and protonated species of metal-ligand complexes. The calculator program of Fabiato and Fabiato [5] is limited by the capabilities of a pocket calculator and is also unable to handle more complex metal-ligand species. While this paper was in review, Stockbridge [6] published a computer program in $C$ language that iteratively calculates the free calcium concentration from the specified total calcium concentration in a solution buffered by EGTA, but it does not permit the calculation of free concentrations of other divalent ions. The present paper describes a computer program written in BASIC and designed to calculate the composition of biologically relevant solutions containing up to 3 metals and 3 ligands.

\section{METHODS}

\section{Computing}

The program was written in IBM BASIC version 3.0. The program was developed on an IBM AT microcomputer with $512 \mathrm{~K}$ bytes random access memory, equipped with an 80-column IBM enhanced color display video monitor, a Paradise Modular Graphics Card (Paradise Systems, Inc., 150 North Hill Drive, Brisbane, CA 94005, U.S.A.), IBM DOS version 3.0, one high capacity floppy drive, and one $20 \mathrm{M}$ byte hard disk drive.

\section{Experimental}

EGTA is widely used to buffer the free concentrations of $\mathrm{Ca}^{2+}$ and $\mathrm{Mg}^{2+}$. The buffering capacity of EGTA for $\mathrm{Ca}^{2+}$ is highly pH-sensitive, however, because the four acetate moieties and two nitrogen atoms which comprise the calcium binding sites on the EGTA molecule can also be protonated [7]. Tsien [7] developed a highly selective $\mathrm{Ca}^{2+}$ buffer, BAPTA, that is less sensitive to changes in $\mathrm{pH}$. For the purpose of this program, BAPTA suffers from 2 drawbacks: (1) stability (association) constants of divalent metal cations other than $\mathrm{Ca}^{2+}$ or $\mathrm{Mg}^{2+}$ are not available and (2) BAPTA is so $\mathrm{Ca}^{2+}$-specific that it no longer buffers $\mathrm{Mg}^{2+}$, and presumably other divalent metal cations, in the desired range $\left(K_{\mathrm{d}}=17 \mathrm{mM}\right.$ for $\mathrm{Mg}^{2+}$ [7]). For a multiple metal and ligand mixture, therefore, EGTA is preferable to BAPTA because of its ability to buffer other divalent cations. The use of ample amounts of Good's buffers such as HEPES or MOPS serves to isolate the EGTA buffer system from changes in $\mathrm{pH}$ that can affect the calcium buffering capacity of EGTA. HEPES and MOPS also have the desirable characteristic of negligible metal binding [8].

\section{CALCULATIONS}

The chemical equilibrium between a metal $M$ and a ligand $L$ is most often represented by the general equation:

$$
\mathrm{M}+\mathrm{L} \rightleftharpoons \mathrm{ML}
$$

The equilibrium is characterized by a stability (formation or association) constant $K$ defined by:

$$
K=\frac{[\mathrm{ML}]}{[\mathrm{M}][\mathrm{L}]}
$$

where $[M L],[M]$ and $[L]$ correspond to the concentrations of the metal-ligand complex, free metal and free ligand, respectively. Each ligand (EGTA, ATP or GTP) can exist in more than one ionic form, depending on the $\mathrm{pH}$. Each metal is capable of binding to one or more ionic forms of a ligand with a stability constant describing each binding reaction. A higher degree of complexity arises from two additional coordination bonding processes: (1) two metal ions can bind to each ligand in certain cases and (2) some chelate complexes can bind $\mathrm{OH}^{-}$to form one or more hydroxo species. In addition, some chelate species can form dimers.

The binding reactions of 3 divalent metal cations to each of the ligands (EGTA, ATP and 
GTP) are illustrated in Appendix 2. The chelation reactions and their respective stability constants were obtained from the compilation of the Martell and Smith $[9,10,11]$ with the exception of $K_{1}-K_{4}$ which was taken from Tsien [7] and $R_{\mathrm{X}}$ for $\mathrm{Ni}^{2+}$ obtained from Sigel [12]. Figure 1 illustrates the equilibria involved in the reaction of a ligand (L) with a metal $\left(\mathrm{M}^{2+}\right)$ where both $\mathrm{L}$ and $\mathrm{ML}$ can accept a proton. Values for $K_{\mathrm{I}}, K_{\mathrm{II}}$ and $K_{\mathrm{IV}}$ were obtained from the literature $[9,10,11]$ and used to derive values for $K_{\mathrm{III}}$ using the relationship $\left(K_{\mathrm{II}}\right)\left(K_{\mathrm{IV}}\right)=\left(K_{\mathrm{I}}\right)\left(K_{\mathrm{III}}\right)$. Schwarzenbach et al. [13] determined experimentally the stability constants of the equilibrium described by $K_{\mathrm{III}}$ for EGTA and $\mathrm{Ca}^{2+}, \mathrm{Mg}^{2+}, \mathrm{Ba}^{2+}$ and $\mathrm{Sr}^{2+}$. The application of the relationship $\left(K_{\mathrm{II}}\right)\left(K_{\mathrm{IV}}\right)=\left(K_{\mathrm{I}}\right)\left(K_{\mathrm{III}}\right)$ yielded values for $K_{\mathrm{III}}$ identical to those measured directly by Schwarzenbach et al. The values of stability constants describing this equilibrium $\left(K_{\mathrm{III}}\right)$ appear in Appendix 2 as the derived values.

The system of equations describing the multiple metal/multiple ligand equilibria and their solution is presented in its entirety in Appendix 3. Briefly, our approach involved starting with a given $\mathrm{pH}$ and concentrations of EGTA, ATP, GTP, free $\mathrm{Ca}^{2+}$, free $\mathrm{Mg}^{2+}$ and free $\mathrm{Cu}^{2+}$ since this set of conditions represented the most complex equilibria. We expressed the total concentration of each ligand as the sum of all its free and bound forms. Then we related all free and bound forms for a given ligand to a single free form of the ligand. This resulted in a relation between the total ligand concentration and the concentration of a single free form of the ligand. Similarly, we expressed the total metal concentration as the sum of all its free and bound forms. Again, we reduced this sum to an expression in terms of the concentration of the same single free form of the ligand. Substituting the relationship between the total ligand concentration and the concentration of the single free form into the expression relating the total metal concentration to the sum of the free and bound forms of the metal, the total metal concentration necessary to achieve a specified free metal concentration can be solved.

\section{PROGRAM DESCRIPTION}

The program display consists of three portions: the menu of parameters and concentrations that can be specified by the user (e.g. pH, [EGTA]), the list of resultant concentrations computed by the program (e.g. total $\left[\mathrm{Ca}^{2+}\right]$ ), and the dialogue box by which the user and the program converse. The program acts as an automatic calculator, updating the results section immediately after each menu parameter is changed. To change any of these parameters, the user moves the selector $(*)$ with the up-arrow and down-arrow keys to the desired menu item, and types the ENTER key. The program will then ask for a new parameter value. The user can either enter a new value or type the ENTER key to exit without making any changes. If the desired parameter is the $\mathrm{pH}$, the user simply types the new $\mathrm{pH}$ value. If the desired parameter is a concentration, then the user must enter both a numerical value and units, in the form " $50 \mathrm{mM}$ " (without quotation marks). If the user wishes to specify a third divalent cation in addition to $\mathrm{Ca}^{2+}$ and $\mathrm{Mg}^{2+}$ (done by moving the selector to the line marked "Cation" and striking the ENTER key), the user will be offered a second cation menu from which to choose. By using the up-, down-, right-, and left-arrow keys to

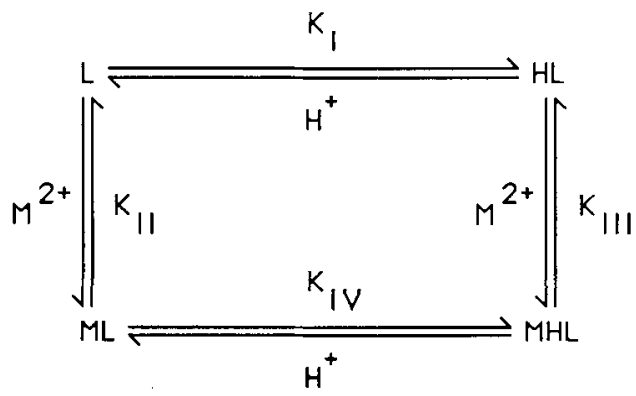

Fig. 1. The equilibria involved in the reaction of a ligand ( $L$ ) with a metal $\left(M^{2+}\right)$ where both $L$ and $M L$ can accept a proton. Values for $K_{1}, K_{11}$ and $K_{\mathrm{IV}}$ were obtained from the literature $[9,10,11]$ and used to derive values for $K_{\mathrm{III}}$ using the relationship $\left(K_{\mathrm{II}}\right)\left(K_{\mathrm{IV}}\right)=\left(K_{\mathrm{I}}\right)\left(K_{\mathrm{III}}\right)$. 
move the selector to the desired cation and typing the ENTER key, one can modify these parameters as many times as desired. Typing the ESC key will allow the user to exit.

Most of the program consists of code to handle the input and output functions. The mathematical portions can be found in three sections. The stability constants for all the reactions not involving a third cation are set in lines 500-599. The stability constants for the optional third divalent metal cation are set in lines $4800-4899$. The subroutine that calculates the results (i.e. the cation distributions and totals) is found in lines 5000-5999. All of the stability constants pertaining to the optional third cation are initially set to zero and modified depending on the user's choice of third cation. In some of the equations, this arrangement could lead to division by zero if the cation chosen does not participate in that particular reaction. To avoid this problem the program equations were rewritten so that instead of dividing by a particular stability constant, $\mathbf{C}_{\mathbf{X} 4}$ for example, the program multiplied by the inverse, called $\mathrm{C}_{\mathrm{X} 4 \mathrm{i}}$. This new stability constant is normally set to zero but is reset to the inverse of $C_{X_{4}}$ when the appropriate cations are chosen. Thus $C_{X_{4}}$ does not appear directly in any of the equations in the calculation subroutine, only indirectly in the form of $\mathrm{C}_{\mathrm{X} 41}$. The situation is similar for $\mathrm{C}_{\mathrm{X} 6}, \mathrm{C}_{\mathrm{X} 7}, \mathbf{R}_{\mathrm{X} 3}, \mathbf{R}_{\mathrm{X} 4}$ and $\mathrm{R}_{\mathrm{X} 5}$.

\section{RESULTS AND DISCUSSION}

Table 1 shows the actual output of the program using the $\mathrm{pH}$ and specified concentrations of free $\mathrm{Ca}^{2+}$, free $\mathrm{Mg}^{2+}$, free $\mathrm{Ba}^{2+}$, EGTA, ATP and GTP. The program displays the total concentration of divalent metal cation needed to achieve a desired free concentration. In addition the output of the program includes the distribution of the bound divalent cation among the various ligands. Data taken from such outputs can be used to construct curves describing the calcium-buffering capacity of EGTA as seen in Fig. 2. Figure 2 illustrates the

Table 1. Screen display of program

\begin{tabular}{|c|c|c|c|c|c|}
\hline $\mathrm{pH}$ & $=7.4$ & & Cotion & ${ }^{*} \mathrm{Ba}$ & $\mathrm{Zn}$ \\
\hline EGTA & 1.000 & $m M$ & Menu & $\mathrm{Sr}$ & Cd \\
\hline ATP & 3.000 & $\mathrm{mM}$ & & $M n$ & $\mathrm{Hg}$ \\
\hline GTP & 1.000 & $\mathrm{mM}$ & & $\mathrm{Fe}$ & $\mathrm{Pb}$ \\
\hline Free Ca & 1.000 & UM & & Co & $\mathrm{Cu}$ \\
\hline Free $\mathrm{Mg}$ & 1.000 & $\mathrm{mM}$ & & $\mathrm{Ni}$ & none \\
\hline Cation & $=B \theta$ & & & & \\
\hline Free Ba & $=$ & & & & \\
\hline
\end{tabular}

\begin{tabular}{|c|c|c|c|c|c|}
\hline & Free & EGTA-bound & ATP-Dound & GTP-bound & Total \\
\hline & 1.000 uM & 42.318 UM & 1.270 UM & $347.665 \mathrm{nM}$ & 44.936 \\
\hline 16 & $1.000 \mathrm{mM}$ & 4.111 UM & $2.714 \mathrm{mM}$ & 914.453 UM & 4.632 \\
\hline & 100.000 UM & 206.575 UM & 42.175 UM & 0.0 & 348.749 \\
\hline
\end{tabular}

Type $\uparrow, t, \rightarrow$, or $\leftarrow$ to move selector $(*)$

〈Enter> to indicote choice

$\langle E S C\rangle$ to quit 


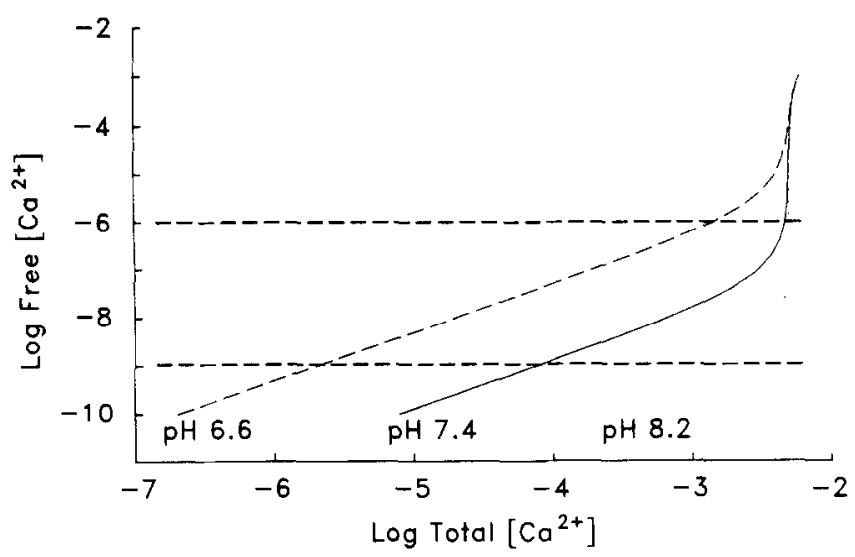

Fig. 2. Effect of $\mathrm{pH}$ on calcium-buffering by EGTA. EGTA concentration was $5 \mathrm{mM}$. Calcium concentration is expressed in moles per liter.

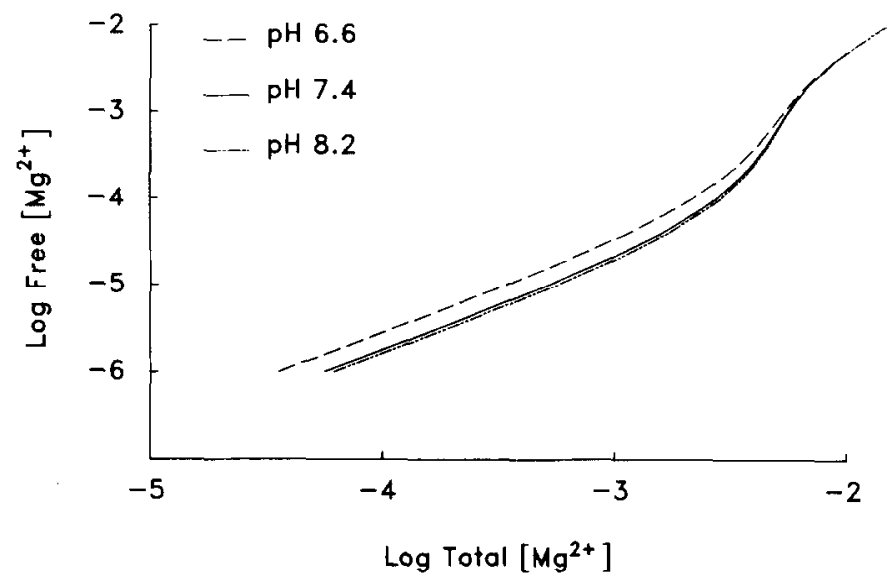

Fig. 3. Effect of $\mathrm{pH}$ on magnesium buffering by ATP. ATP concentration was $5 \mathrm{mM}$. Magnesium concentration is expressed in moles per liter.

$\mathrm{pH}$ sensitivity of calcium-buffering by EGTA. At $\mathrm{pH} 6.6$, free $\mathrm{Ca}^{2+}$ concentrations in the 1 $\mathrm{nM}$ to $1 \mu \mathrm{M}$ range are located on a relatively "flat" portion of the titration curve. In contrast, at $\mathrm{pH} 8.2 \mathrm{free}^{\mathrm{Ca}^{2+}}$ concentrations greater than $10 \mathrm{nM}$ fall on a relatively "steep" portion of the titration curve. The relative lack of $\mathrm{pH}$ sensitivity in the $\mathrm{Mg}^{2+}$-buffering capacity of ATP is shown in Fig. 3.

The biological role of divalent metal cations continues to be of great interest in the study of cellular regulation and signal transduction mechanisms [1,2]. This computer program facilitates the formulation of chemical solutions for use in studies requiring the control of levels of free divalent metal cations such as $\mathrm{Ca}^{2+}$. In addition the program enables the investigator to include important substrates such as ATP and GTP and to account for their effects on divalent cation activity. The law of mass action provides the theoretical basis for calculating the equilibrium concentrations of free and bound divalent cations in solutions containing several complex-forming species, given the proper stability constants, but it is important that the user be aware of the limitations of this approach. First, the stability constants used in this program were obtained under well-defined experimental conditions of temperature $\left(20-25^{\circ} \mathrm{C}\right)$ and ionic strength $(0.1 \mathrm{M})$. The application of this program to conditions that deviate significantly from these may not be valid. Second, the program does not include the participation of known and unknown biologically active complexing species. This problem can be circumvented by using a volume of solution that is large in comparison to that of the biological components. This procedure ensures that the equilibrium of the 
formulated chemical solution dominates the entire system. Finally a persistent drawback to this approach is the lack of data for mixed cation-ligand complexes (e.g. $\mathrm{Cu}-\mathrm{Ni}$-EGTA). There is no convenient and accurate method of determining the extent to which these species participate in the equilibria discussed above.

This program has been used in our laboratory to design solutions appropriate for the study of the activation of membrane ion channels by calcium $[14,15]$. The program is very easy to use and permits the user to formulate the divalent cation buffer solutions which would be applicable to a variety of studics which require precise control of ambient calcium activity: single channel recording [16], protein phosphorylation [17], signal transduction by GTP-binding proteins [18] and calibration of quin2 and fura-2 [19] fluorescence signals.

\section{A VAILABILITY}

The CALCIUM program copyright is held by the University of Michigan, and its distribution is handled by the University Intellectual Properties Office. For further information on licensing and fees please contact Ms Beth Gehrman, University of Michigan Software, Intellectual Properties Office, 225 West Engineering, Ann Arbor, MI 48109-1092; tel. no. (313) 936-0435.

\section{SUMMARY}

A BASIC microcomputer program has been developed to assist the rapid design of the chemical composition of solutions with specified concentrations of free divalent metal cations. This program allows the user to employ as many as 3 ligands (EGTA, ATP and GTP) at any $\mathbf{p H}$ to obtain the desired free concentration of up to 3 divalent cations $\left(\mathrm{Ca}^{2+}\right.$, $\mathrm{Mg}^{2+}$ and the choice of a third). The user enters the $\mathrm{pH}$, the concentrations of the ligands used and the desired free divalent cation concentrations. The program computes the total concentration of divalent metal cation needed to achieve the specified free divalent cation concentration. This program is based on the law of mass action and the absolute stability (association) constants found in the literature. A discussion of the utility of the program and the limitations/assumptions of the method used is presented. The program has potential applications in a variety of biological studies, particularly those involving the design of solutions which mimic certain aspects of the intracellular fluid.

Acknowledgements - Special thanks are due to Dr Ronald W. Holz whose early work on these computations with a pocket calculator inspired us to pursue a more expeditious solution. This work was supported by the following grants to D. C. Dawson: NIH AM32901 and NIH AM29786.

\section{REFERENCES}

1. A. K. Campbell, Intracellular Calcium: its Universal Role as Regulator. John Wiley, Chichester (1983).

2. R. P. Rubin, G. B. Weiss and J. W. Putney, Jr, Eds, Calcium in Biological Systems. Plenum Press, New York (1985).

3. A. C. Dolphin, Nucleotide binding proteins in signal transduction and disease, Trends Neurasci. 10, 53-57 (1987).

4. D. D. Perrin and I. G. Sayce, Computer calculation of equilibrium concentrations in mixtures of metal ions and complexing species, Talanta 14, 833-842 (1967).

5. A. Fabiato and F. Fabiato, Calculator programs for computing the composition of solutions containing multiple metals and ligands used for experiments in skinned muscle cells, J. Physiol., Paris 75, 463-505 (1979).

6. N. Stockbridge, EGTA, Comput. Biol. Med. 17, 299-304 (1987).

7. R. Y. Tsien, New calcium indicators and buffers with high selectivity against magnesium and protons: design, synthesis, and properties of prototype structures, Biochemistry 19, 2396-2404 (1980).

8. N. E. Good and S. Izawa, Hydrogen ion buffers, Meth. Enzym. 24 (B), 53-68 (1968).

9. A. E. Martell and R. M. Smith, Critical Stability Constants, Vol. 1. Plenum Press, New York (1974).

10. A. E. Martell and R. M. Smith, Critical Stability Constants, Vol. 2. Plenum Press, New York (1975).

11. A. E. Martell and R. M. Smith, Critical Stability Constants, Vol. 5. Plenum Press, New York (1982).

12. H. Sigel, Nucleic base-metal ion interactions. Acidity of the N(1) or N(3) proton in binary and ternary complexes of $\mathrm{Mn}^{2+}, \mathrm{Ni}^{2+}$, and $\mathrm{Zn}^{2+}$ with the $\mathrm{S}^{\prime}$-triphosphates of inosine, guanosine, uridine, and thymidine, J. Am. chem. Soc. 97, 3209-3214 (1975).

13. G. Schwarzenbach, H. Senn and G. Anderegg, Komplexone XXIX. Ein grosser Chelateffekt besonderer Art, Helv. chim. Acta 40, 1886-1900 (1957). 
14. D. Chang and D. C. Dawson, Digitonin-permeabilized colonic cell layers: Demonstration of calcium-activated basolateral $\mathrm{K}$ and $\mathrm{Cl}$ conductances, J. gen. Physiol. (in press).

15. N. W. Richards, R. J. Lowy, S. A. Ernst and D. C. Dawson, Single K channels in a model $\mathrm{Cl}^{-}$secretory epithelium: The avian salt gland (submitted).

16. B. Sakmann and E. Hener, Eds, Single-Channel Recording. Plenum Press, New York (1983).

17. S. A. Lee and R. W. Holz, Protein phosphorylation and secretion in digitonin-permeabilized adrenal chromaffin cells, J. biol. Chem. 261, 17089-17098 (1986).

18. A. Gilman, G proteins and dual control of adenylate cyclase, Cell 36, 577-579 (1984)

19. G. Grynkiewicz, M. Poenie and R. Y. Tsien, A new generation of $\mathrm{Ca}^{2+}$ indicators with greatly improved fluorescence properties, J. biol. Chem. 260, 3440-3450 (1985).

\begin{abstract}
About the Author--Dean Chang received his B.A. degree in Chemistry from the Johns Hopkins University in 1983. He is currently in his fifth year of the Medical Scientist Training Program at the University of Michigan and is pursuing his Ph.D. degree in the Cellular and Molecular Biology Program. His research interests include the regulation of ion channels in cells by calcium and other intracellular second messengers.
\end{abstract}

About the Author-Paul Sek-Bin Hsien received his B.S. degree in Mathematics from the Massachusetts Institute of Technology in 1984. In 1987 he completed a year of research in the laboratory of Dr Robert S. Balaban at the NIH as a Howard Hughes Medical Institute-NIH Research Scholar. He is currently a third-year medical student at the University of Michigan Medical School His research interests include computer modeling of biological systems and medical applications of digital image processing.

\begin{abstract}
About the Author-David CHARLES DAwson received his B.S. degree in Electrical Engineering and his Ph.D. degree in Comparative Physiology from the University of Pittsburgh in 1966 and 1971, respectively. He then completed a NIH Postdoctoral Fellowship in Membrane Biophysics with Professor Peter F. Curran in the Department of Physiology at the Yale University School of Medicine in 1973. From 1973 to 1981 he was an Assistant Professor and later an Associate Professor in the Department of Physiology and Biophysics at the University of Iowa. From 1979 to 1984 he was a recipient of a NIAMDD Research Career Development Award, and he is currently Professor of Physiology at the University of Michigan Medical School. His research interests are directed toward understanding the biophysical mechanisms and control of ion transport processes in the plasma membranes of epithelial cells.

Dr Dawson is a member of the Biophysical Society, American Physiological Society, Society of General Physiologists, American Association for the Advancement of Science, and the Mount Desert Island Biological Laboratory.
\end{abstract}

APPENDIX 1: NOMENCLATURE

$\mathrm{L}_{1}$
$\mathrm{~L}_{2}$
$\mathrm{~L}_{3}$
$\mathrm{H}^{\prime}$
$[\mathrm{l}]$
$\left[\mathrm{Ca}^{2+}\right]$
$\left[\mathrm{Mg}^{2+}\right]$
$\left[\mathrm{Cu}^{2+}\right]$
$\left[\mathrm{X}^{2+}\right]$

EGTA (ligand 1)

ATP (ligand 2)

GTP (ligand 3)

Amide-like hydrogen at $\mathrm{N}(3)$ of guanine

Concentration of $I$ in moles per liter

Free $\left[\mathrm{Ca}^{2+}\right]$

Free $\left[\mathrm{Mg}^{2+}\right]$

Free $\left[\mathrm{Cu}^{2+}\right]$

Free [divalent cation $\mathrm{X}^{2+}$ ]

\title{
Subscripts
}


358

Dean Chang et al.

APPENDIX 2: CHEMICAL EQUILIBRIA AND STABILITY CONSTANTS

$$
L_{1}^{4-} \underset{K_{4}}{\rightleftharpoons} \mathrm{L}_{1}^{3-} \underset{\mathrm{K}_{3}}{\rightleftharpoons} \mathrm{H}_{2} \mathrm{~L}_{1}^{2-} \underset{\mathrm{K}_{2}}{\rightleftharpoons} \mathrm{H}_{3} \mathrm{~L}_{1}^{-} \underset{\mathrm{K}_{1}}{\rightleftharpoons} \mathrm{H}_{4} \mathrm{~L}_{1}
$$

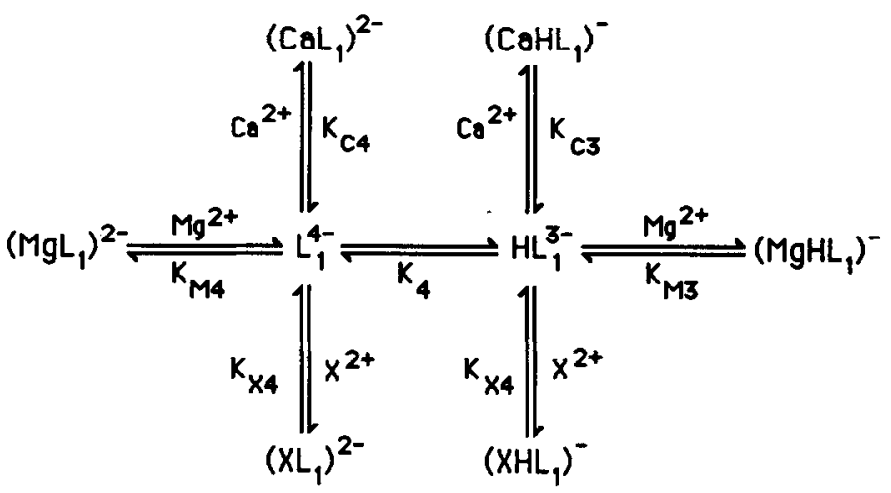

$$
\begin{aligned}
\mathrm{X}^{2+}= & \mathrm{Sr}^{2+}, \mathrm{Ba}^{2+}, \mathrm{Mn}^{2+}, \mathrm{Fe}^{2+}, \mathrm{Co}^{2+}, \mathrm{Ni}^{2+}, \\
& \mathrm{Zn}^{2+}, \mathrm{Cd}^{2+}, \mathrm{Hg}^{2+}, \mathrm{Pb}^{2+}, \mathrm{Cu}^{2+}
\end{aligned}
$$

$$
\begin{aligned}
& \left(\mathrm{XL}_{1}\right)^{2-}+\mathrm{X}^{2+} \underset{\mathrm{K}_{\mathrm{X} 2}}{\rightleftharpoons}\left(\mathrm{X}_{2} \mathrm{~L}_{1}\right) \\
& \mathrm{X}^{2+}=\mathrm{Co}^{2+}, \mathrm{Ni}^{2+}, \mathrm{Zn}^{2+}, \mathrm{Pb}^{2+}, \mathrm{Cu}^{2+}
\end{aligned}
$$




$$
\begin{aligned}
& \mathrm{X}_{2} \mathrm{~L}_{1}+\mathrm{OH}^{-} \underset{\mathrm{K}_{X 5}}{\rightleftharpoons}\left[\mathrm{X}_{2}(\mathrm{OH}) \mathrm{L}_{1}\right]^{-}+\mathrm{OH}^{-} \underset{\mathrm{K}_{\mathrm{X}}}{\rightleftharpoons}\left[\mathrm{X}_{2}(\mathrm{OH})_{2} \mathrm{~L}_{1}\right]^{2-} \\
& \mathrm{X}^{2+}=\mathrm{Cu}^{2+}
\end{aligned}
$$

$$
\mathrm{L}_{2}^{4-} \underset{\mathrm{C}_{3}}{\rightleftharpoons} \mathrm{HL}_{2}^{3-} \rightleftharpoons \mathrm{C}_{2} \mathrm{H}_{2} \mathrm{~L}_{2}^{2-}
$$

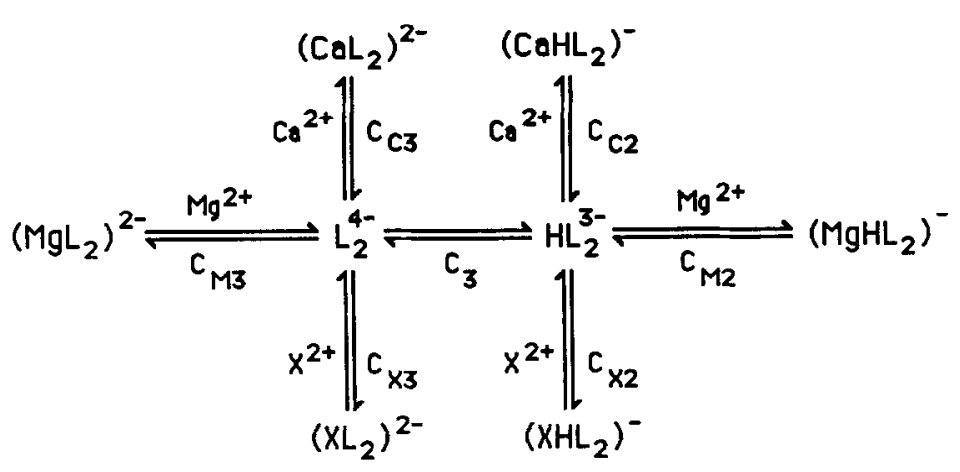

$$
\mathrm{X}^{2+}=\mathrm{Sr}^{2+}, \mathrm{Ba}^{2+}, \mathrm{Mn}^{2+}, \mathrm{Co}^{2+}, \mathrm{Ni}^{2+}, \mathrm{Zn}^{2+}, \mathrm{Cu}^{2+}
$$




$$
\begin{aligned}
& \left(\mathrm{XL}_{2}\right)^{2-} \underset{\mathrm{C}_{4}}{\stackrel{\mathrm{H}_{2} \mathrm{O}}{\rightleftharpoons}}\left[X(\mathrm{OH}) \mathrm{L}_{2}\right]^{3-}+\mathrm{H}^{+} \\
& \mathrm{X}^{2+}=\mathrm{Cu}^{2+}, \mathrm{Zn}^{2+}
\end{aligned}
$$

$$
\begin{aligned}
& 2\left[X(\mathrm{OH}) \mathrm{L}_{2}\right]^{3-} \underset{\mathrm{C}_{X 5}}{\rightleftharpoons}\left\{\left[X(\mathrm{OH}) \mathrm{L}_{2}\right]^{3-}\right\}_{2} \\
& \left\{\left[X(\mathrm{OH}) \mathrm{L}_{2}\right]^{3-}\right\}_{2}+2 \mathrm{H}^{+} \underset{\mathrm{C}_{X 6}}{\rightleftharpoons} 2\left(\mathrm{XL}_{2}\right)^{2-}+2 \mathrm{H}_{2} \mathrm{O} \\
& {\left[X(\mathrm{OH}) \mathrm{L}_{2}\right]^{3-} \underset{\mathrm{C}_{X 7}}{\rightleftharpoons}\left[X(\mathrm{OH})_{2} \mathrm{~L}_{2}\right]^{4-}+\mathrm{H}^{+}} \\
& \mathrm{C}^{2+}=\mathrm{Cu}^{2+}
\end{aligned}
$$




$$
\mathrm{L}_{3}^{5-} \underset{R_{3}}{\rightleftharpoons} \mathrm{HL}_{3}^{4-} \underset{\mathrm{R}_{2}}{\rightleftharpoons} \mathrm{H}^{\prime} \mathrm{HL}_{3}^{3-} \underset{\mathrm{R}_{1}}{\rightleftharpoons} \mathrm{H}_{2} \mathrm{H}_{3} \mathrm{~L}_{3}^{2-}
$$

$$
\begin{aligned}
& \left(\mathrm{CaH}^{\prime} \mathrm{L}_{3}\right)^{2-} \underset{\mathrm{R}_{\mathrm{C}}}{\stackrel{\mathrm{Co}^{2+}}{\rightleftharpoons}} \mathrm{HL}_{3}^{4-} \underset{\mathrm{R}_{M}}{\stackrel{\mathrm{Mg}^{2+}}{\rightleftharpoons}}\left(\mathrm{MgH}_{3}\right)^{2-} \\
& x^{2+} \|_{\left(X H^{\prime} L_{3}\right)^{2-}} R_{X}
\end{aligned}
$$

$$
\mathrm{X}^{2+}=\mathrm{Mn}^{2+}, \mathrm{Zn}^{2+}, \mathrm{Co}^{2+}, \mathrm{Cu}^{2+}, \mathrm{Ni}^{2+}
$$

$$
\begin{aligned}
& \mathrm{L}_{3}^{5-}+\mathrm{X}^{2+} \underset{\mathrm{R}_{\mathrm{X} 2}}{\rightleftharpoons}\left(\mathrm{XL}_{3}\right)^{3-} \underset{\mathrm{R}_{\mathrm{X} 3}}{\stackrel{\mathrm{H}_{2} \mathrm{O}}{\rightleftharpoons}\left[\mathrm{X}(\mathrm{OH}) \mathrm{L}_{3}\right]^{4-}+\mathrm{H}^{+}} \\
& \mathrm{X}^{2+}=\mathrm{Mn}^{2+}, \mathrm{Ni}^{2+}, \mathrm{Cu}^{2+}, \mathrm{Zn}^{2+}
\end{aligned}
$$

$$
\left(X H^{\prime} \mathrm{L}_{3}\right)^{2-} \frac{\mathrm{H}_{2} \mathrm{O}}{\mathrm{R}_{\mathrm{X} 4}}\left[X(\mathrm{OH}) \mathrm{H}^{\prime} \mathrm{L}_{3}\right]^{3-}+\mathrm{H}^{+}
$$

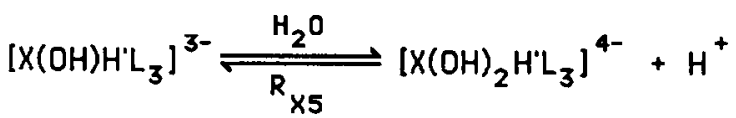

$$
\mathrm{x}^{2+}=\mathrm{Cu}^{2+}
$$




$$
\begin{aligned}
& K_{1}=2.12 \\
& K_{2}=2.80 \\
& K_{3}=8.97 \\
& K_{4}=9.59
\end{aligned}
$$$$
K_{\mathrm{C}_{4}}=10.97
$$$$
K_{\mathrm{C} 3}=5.29
$$$$
K_{M 4}=5.21
$$$$
K_{M 3}=3.36
$$

Divalent $\mathrm{X}^{2+}$

$$
\begin{aligned}
& \mathrm{Ba}^{2+} \\
& \mathrm{Sr}^{2+} \\
& \mathrm{Mn}^{2+} \\
& \mathrm{Fe}^{2+} \\
& \mathrm{Co}^{2+} \\
& \mathrm{Ni}^{2+} \\
& \mathrm{Cu}^{2+} \\
& \mathrm{Zn}^{2+} \\
& \mathrm{Cd}^{2+} \\
& \mathrm{Hg}^{2+} \\
& \mathrm{Pb}^{2+}
\end{aligned}
$$

$$
\mathrm{K}_{\mathrm{X} 3}
$$$$
4.25
$$

8.41

8.50

12.28

11.87

12.39

13.55

17.71

12.70

16.70

23.20

14.71

$$
4.36
$$$$
6.91
$$$$
6.70
$$

8.02

9.18

12.60

8.19

10.70

16.75

10.40
$\mathrm{K}_{\mathrm{X} 2}$

$\mathrm{K}_{\mathrm{X5}}$

$\mathrm{K}_{\mathrm{X6}}$

3.30

4.90

4.31

3.30

6.90

5.80 
$C_{2}=4.05$
$C_{3}=6.51$

$$
\begin{aligned}
& c_{C_{3}}=3.77 \\
& c_{C_{2}}=1.95
\end{aligned}
$$$$
C_{M 3}=4.10
$$$$
C_{M 2}=2.14
$$

Divalent $\mathbf{X}^{2+}$

$$
c_{x 3}
$$

$$
c_{x 2}
$$

$c_{X 4}$

$c_{X 5}$

$c_{x 6}$

$c_{x 7}$

$\mathrm{Ba}^{2+}$
$\mathrm{Sr}^{2+}$
$\mathrm{Mn}^{2+}$
$\mathrm{Co}^{2+}$
$\mathrm{Ni}^{2+}$
$\mathrm{Zn}^{2+}$
$\mathrm{Cu}^{2+}$

3.29

1.87

$3.54 \quad 2.07$

$\begin{array}{ll}4.74 & 2.37\end{array}$

$4.63 \quad 2.31$

$5.02 \quad 2.74$

$4.80 \quad 2.64$

8.76

$6.00 \quad 3.01$

6.47

2.59

10.35

7.45

$$
\begin{aligned}
& R_{1}=3.30 \\
& R_{2}=6.45 \\
& R_{3}=9.50
\end{aligned}
$$$$
R_{C}=3.66
$$

$$
R_{M}=4.08
$$

Divalent $\mathrm{X}^{2+}$

$R_{x}$

$\mathrm{A}_{\mathrm{X} 2}$

$R_{X 3}$

$\mathrm{R}_{\mathrm{X} 4}$

$\mathrm{R}_{\mathbf{X 5}}$

$\mathrm{Mn}^{2+}$

$\mathrm{Zn}^{2+}$

$\mathrm{Co}^{2+}$

$\mathrm{Cu}^{2+}$

$\mathrm{Ni}^{2+}$

4.69

4.94

11.2

4.96

6.18

9.37

5.93

7.83

5.82

9.30

10.46

7.60

9.30 
We started by specifying the $\mathrm{pH}$, [EGTA], [ATP], [GTP], free $\left[\mathrm{Ca}^{2+}\right]$, free $\left[\mathrm{Mg}^{2+}\right]$ and free $\left[\mathrm{Cu}^{2+}\right]$ since this set of conditions presents the most complex equilibria. By the principles of mass action and conservation of mass, the total amount of each ligand is equal to the sum of the individual free and complexed species. We can express all forms of $L_{1}$ in terms of $L_{1}{ }^{4-}$ :

(1) $\left[L_{1}\right]_{T}=\left[L_{1}{ }^{4-}\right] \cdot \alpha$ where

$$
\begin{aligned}
\alpha=\left\{1+\left[\mathrm{H}^{+}\right] \mathrm{K}_{4}\left(1+\left[\mathrm{H}^{+}\right] \mathrm{K}_{3}+\left[\mathrm{H}^{+}\right]^{2} \mathrm{~K}_{3} \mathrm{~K}_{2}+\left[\mathrm{H}^{+}\right]^{3} \mathrm{~K}_{3} \mathrm{~K}_{2} \mathrm{~K}_{1}\right)\right. \\
+\left[\mathrm{Ca}^{2+}\right]\left(\mathrm{K}_{\mathrm{C} 4}+\left[\mathrm{H}^{+}\right] \mathrm{K}_{4} \mathrm{~K}_{\mathrm{C} 3}\right)+\left[\mathrm{Mg}^{2+}\right]\left(\mathrm{K}_{\mathrm{M} 4}+\left[\mathrm{H}^{+}\right] \mathrm{K}_{4} \mathrm{~K}_{\mathrm{M} 3}\right) \\
+\left[\mathrm{Cu}^{2+}\right]\left(\mathrm{K}_{\mathrm{X} 4}+\left[\mathrm{H}^{+}\right] \mathrm{K}_{4} \mathrm{~K}_{\mathrm{X} 3}\right) \\
\left.+\left[\mathrm{Cu}^{2+}\right]^{2} \mathrm{~K}_{\mathrm{X} 4} \mathrm{~K}_{\mathrm{X} 2}\left(1+\left[\mathrm{OH}^{-}\right] \mathrm{K}_{\mathrm{X} 5}+\left[\mathrm{OH}^{-}\right]^{2} \mathrm{~K}_{\mathrm{X} 5} \mathrm{~K}_{\mathrm{X} 6}\right)\right\}
\end{aligned}
$$

We can express all forms of $L_{2}$ in terms of $L_{2}^{4-:}$

(2) $\left[L_{2}\right]_{T}=\left[L_{2}^{4-}\right] \cdot \beta+\left[L_{2}^{4-}\right]^{2} \cdot \gamma \quad$ where

$$
\begin{aligned}
& \beta=\left\{1+\left[\mathrm{H}^{+}\right] \mathrm{C}_{3}\left(1+\left[\mathrm{H}^{+}\right] \mathrm{C}_{2}\right)+\left[\mathrm{Ca}^{2+}\right]\left(\mathrm{C}_{\mathrm{C} 3}+\left[\mathrm{H}^{+}\right] \mathrm{C}_{3} \mathrm{C}_{\mathrm{C} 2}\right)\right. \\
& +\left[\mathrm{Mg}^{2+}\right]\left(\mathrm{C}_{\mathrm{M3}}+\left[\mathrm{H}^{+}\right] \mathrm{C}_{3} \mathrm{C}_{\mathrm{M} 2}\right) \\
& +\left[\mathrm{Cu}^{2+}\right]\left(\mathrm{C}_{\mathrm{X} 3}+\left[\mathrm{H}^{+}\right] \mathrm{C}_{3} \mathrm{C}_{\mathrm{X} 2}+\mathrm{C}_{\mathrm{X} 3} / \mathrm{C}_{\mathrm{X} 4}\left[\mathrm{H}^{+}\right]\right. \\
& \left.\left.+\mathrm{C}_{\mathrm{X} 3} /\left[\mathrm{H}^{+}\right]^{2} \mathrm{C}_{\mathrm{x}_{4}} \mathrm{C}_{\mathrm{x} 7}\right)\right\} \\
& \gamma=\left\{\left(\left[\mathrm{Cu}^{2+} \mathrm{C}_{\mathrm{X} 3} /\left[\mathrm{H}^{+}\right]\right)^{2} / \mathrm{C}_{\mathrm{X} 6}\right\}\right.
\end{aligned}
$$


We can express all forms of $L_{3}$ in terms of $L_{3}{ }^{5 *}$ :

(3) $\left[L_{3}\right]_{T}=\left[L_{3}{ }^{5}\right] \cdot \delta$ where

$$
\begin{gathered}
\delta=\left\{1+\left[\mathrm{H}^{+}\right] \mathrm{R}_{3}\left(1+\left[\mathrm{H}^{+}\right] \mathrm{R}_{2}+\left[\mathrm{H}^{+}\right]^{2} \mathrm{R}_{2} \mathrm{R}_{1}\right)\right. \\
+\left[\mathrm{H}^{+}\right] \mathrm{R}_{3}\left(\mathrm{R}_{\mathrm{C}}\left[\mathrm{Ca}^{2+}\right]+\mathrm{R}_{\mathrm{M}}\left[\mathrm{Mg}^{2+}\right]+\mathrm{R}_{\mathrm{X}}\left[\mathrm{Cu}^{2+}\right]\right) \\
+\left[\mathrm{Cu}^{2+}\right]\left(\mathrm{R}_{\mathrm{X} 2}+\mathrm{R}_{\mathrm{X} 2} /\left[\mathrm{H}^{+}\right] \mathrm{R}_{\mathrm{X} 3}+\mathrm{R}_{\mathrm{X}} \mathrm{R}_{3} / \mathrm{R}_{\mathrm{X} 4}\right. \\
\left.\left.+\mathrm{R}_{\mathrm{X}} \mathrm{R}_{3} /\left[\mathrm{H}^{+}\right] \mathrm{R}_{\mathrm{X} 5} \mathrm{R}_{\mathrm{X} 4}\right)\right\}
\end{gathered}
$$

We can also relate $\left[\mathrm{OH}^{-}\right]$to $\left[\mathrm{H}^{+}\right]$with (4) $\left[\mathrm{OH}^{-}\right]=10^{-14} /\left[\mathrm{H}^{+}\right]$.

We can now express $\left[\mathrm{L}_{1}{ }^{4-}\right],\left[\mathrm{L}_{2}{ }^{4-}\right]$ and $\left[\mathrm{L}_{3}{ }^{5-}\right]$ as:

(5) $\left[L_{1}{ }^{4-}\right]=\left[L_{1}\right]_{T} / \alpha$

(6) $\left[L_{2}{ }^{4-}\right]=\left\{-\beta \pm\left(\beta^{2}-4 \gamma\left[L_{2}\right]_{T}\right)^{1 / 2}\right\} / 2 \gamma$ where $0 \leq\left[L_{2}{ }^{4-}\right] \leq\left[L_{2}\right]_{T}$

(7) $\left[L_{3}{ }^{5-}\right]=\left[L_{3}\right]_{T} / \delta$

Similarly, the total concentration of each divalent metal cation is equal to the sum of the free and bound forms. The expressions representing these relationships are as follows:

(8) $\left[\mathrm{Ca}^{2+}\right]_{\mathrm{T}}=\left[\mathrm{Ca}^{2+}\right]\left\{1+\left[\mathrm{L}_{1}{ }^{4-}\right]\left(\mathrm{K}_{\mathrm{C} 4}+\mathrm{K}_{4} \mathrm{~K}_{\mathrm{C} 3}\left[\mathrm{H}^{+}\right]\right)\right.$

$$
\begin{aligned}
& +\left[\mathrm{L}_{2}{ }^{4-}\right]\left(\mathrm{C}_{\mathrm{C} 3}+\mathrm{C}_{3} \mathrm{C}_{\mathrm{C} 2}\left[\mathrm{H}^{+}\right]\right) \\
& \left.+\left[\mathrm{L}_{3}{ }^{5}\right]\left(\mathrm{R}_{3} \mathrm{R}_{\mathrm{C}}\left[\mathrm{H}^{+}\right]\right)\right\}
\end{aligned}
$$


(9) $\left[\mathrm{Mg}^{2+}\right]_{\mathrm{T}}=\left[\mathrm{Mg}^{2+}\right]\left\{1+\left[\mathrm{L}_{1}{ }^{4-}\right]\left(\mathrm{K}_{\mathrm{M4}}+\mathrm{K}_{4} \mathrm{~K}_{\mathrm{M} 3}\left[\mathrm{H}^{+}\right]\right)\right.$

$$
\begin{aligned}
& +\left[L_{2}^{4-}\right]\left(C_{M 3}+C_{3} C_{M 2}\left[H^{+}\right]\right) \\
& \left.+\left[L_{3}^{5-}\right]\left(R_{3} R_{M}\left[H^{+}\right]\right)\right\}
\end{aligned}
$$

$$
\begin{aligned}
& \text { (10) }\left[\mathrm{Cu}^{2+}\right]_{T}=\left[\mathrm{Cu}^{2+}\right]\left\{1+\left[\mathrm{L}_{1}{ }^{4-}\right]\left(\mathrm{K}_{\mathrm{X} 4}+\mathrm{K}_{4} \mathrm{~K}_{\mathrm{X}}\left[\mathrm{H}^{+}\right]\right)\right. \\
& +\left[\mathrm{L}_{2}{ }^{4-}\right]\left(\mathrm{C}_{x_{3}}+\mathrm{C}_{3} \mathrm{C}_{x_{2}}\left[\mathrm{H}^{+}\right]+\mathrm{C}_{x_{3}} / \mathrm{C}_{x_{4}}\left[\mathrm{H}^{+}\right]\right. \\
& \left.+\mathrm{C}_{\mathrm{X}_{3}} /\left[\mathrm{H}^{+}\right]^{2} \mathrm{C}_{\mathrm{X} 4} \mathrm{C}_{\mathrm{X} 7}\right) \\
& +\left[L_{3}^{5-}\right]\left(R_{3} R_{x}\left[H^{+}\right]+R_{x 2}+R_{x 2} /\left[H^{+}\right] R_{x 3}\right. \\
& +R_{X} R_{3} / R_{X 4} \\
& \left.+R_{X} R_{3}\left[\left(H^{+}\right] R_{x 5} R_{4}\right)\right\} \\
& +\left[\mathrm{Cu}^{2+}\right]^{2}\left\{[ \mathrm { L } _ { 1 } { } ^ { 4 - } ] \left(\mathrm{~K}_{\mathrm{X}_{4}} \mathrm{~K}_{\mathrm{X}_{2}}+\mathrm{K}_{\mathrm{X}_{4}} \mathrm{~K}_{\mathrm{X}_{2}} \mathrm{~K}_{\mathrm{X} 5}\left[\mathrm{OH}^{-}\right]\right.\right. \\
& \left.+\mathrm{K}_{\mathrm{x}_{4}} \mathrm{~K}_{\mathrm{x}_{2}} \mathrm{~K}_{\mathrm{x}_{5}} \mathrm{~K}_{\mathrm{x} 6}\left[\mathrm{OH}^{-}\right]^{2}\right) \\
& \left.+\left[\mathrm{L}_{2}^{4-}\right]^{2}\left(\mathrm{C}_{\mathrm{X} 3}\right)^{2} /\left[\mathrm{H}^{+}\right]^{2} \mathrm{C}_{\mathrm{X} 6}\right\}
\end{aligned}
$$

Using specified input values for $\mathrm{pH}$, [EGTA], [ATP], [GTP], free $\left[\mathrm{Ca}^{2+}\right]$, free $\left[\mathrm{Mg}^{2+}\right]$ and free $\left[\mathrm{Cu}^{2+}\right]$ with the appropriate stability constants in equations (1) - (10) we can calculate the total concentrations of $\mathrm{Ca}^{2+}, \mathrm{Mg}^{2+}$ and $\mathrm{Cu}^{2+}$ needed to achieve the desired ionic conditions. 